\title{
The Wages of Crying Wolf: A Comment on Roe v. Wade*
}

\author{
John Hart Ely**
}

The interests of the mother and the fetus are opposed. On which side should the State throw its weight? The issue is volatile; and it is resolved by the moral code which an individual has. ${ }^{1}$

In Roe v. Wade, ${ }^{2}$ decided January 22, 1973, the Supreme CourtJustice Blackmun speaking for everyone but Justices White and Rehnquist ${ }^{3}$-held unconstitutional Texas's (and virtually every other state's ${ }^{4}$ ) criminal abortion statute. The broad outlines of its argument are not difficult to make out:

1. The right to privacy, though not explicitly mentioned in the Constitution, is protected by the Due Process Clause of the Fourteenth Amendment. ${ }^{5}$

2. This right "is broad enough to encompass a woman's decision whether or not to terminate her pregnancy."

3. This right to an abortion is "fundamental" and can therefore be regulated only on the basis of a "compelling" state interest. ${ }^{7}$

4. The state does have two "important and legitimate" interests here, ${ }^{8}$ the first in protecting maternal health, the second in protecting the life (or potential life ${ }^{0}$ ) of the fetus. ${ }^{10}$ But neither can be counted "compelling" throughout the entire pregnancy: Each matures with the unborn child.

These interests are separate and distinct. Each grows in substan-

* Copyright (C) 1973 by John Hart Ely.

* Professor of Law, Yale Law School.

1. United States v. Vuitch, 402 U.S. 62, 80 (1971) (Douglas, J., dissenting in part).

2. 93 S. Ct. 705 (1973).

3. Were the dissents adequate, this comment would be unnccessary. But cach is so brief as to signal no particular conviction that Roe represents an important, or unusually dangerous, constitutional development.

4. See 93 S. Ct. at 709.10 n.2. See also Doe v. Bolton, 93 S. Ct. 739, 742 (1973).

5. Id. at 727. But cf. note 58 infra.

6. $93 \mathrm{~S}$. Ct. at 727.

7. Id. at 728 .

8. Id. at 731 .

9. The Court indicates that the constitutional issue is not to be solved by attempting to answer "the difficult question of when life begins." Id. at 730. See also id. at 725 . But see pp. 925-26 infra.

10. The suggestion that the interest in protecting prenatal life should not be con. sidered because the original legislative history of most laws restricting abortion concerned itself with maternal health, see $93 \mathrm{~S}$. Ct. at $725-26$, is rightly rejected-by clear implication in Roe and rather explicitly in Doe. Id. at 747 . 
tiality as the woman approaches term and, at a point during pregnancy, each becomes "compelling."11

5. During the first trimester of pregnancy, neither interest is sufficiently compelling to justify any interference with the decision of the woman and her physician. Appellants have referred the Court to medical data indicating that mortality rates for women undergoing early abortions, where abortion is legal, "appear to be as low as or lower than the rates for normal childbirth."12 Thus the state's interest in protecting maternal health is not compelling during the first trimester. Since the interest in protecting the fetus is not yet compelling either, ${ }^{13}$ during the first trimester the state can neither prohibit an abortion nor regulate the conditions under which one is performed. ${ }^{14}$

6. As we move into the second trimester, the interest in protecting the fetus remains less than compelling, and the decision to have an abortion thus continues to control. However, at this point the health risks of abortion begin to exceed those of childbirth. "It follows that, from and after this point, a State may regulate the abortion procedure to the extent that the regulation reasonably relates to the preservation and protection of maternal health."15 Abortion may not be prohibited during the second trimester, however. ${ }^{10}$

7. At the point at which the fetus becomes viable ${ }^{17}$ the interest in protecting it becomes compelling, ${ }^{18}$ and therefore from that point on the state can prohibit abortions except-and this limitation is also apparently a constitutional command, though it receives no justification in the opinion-when they are necessary to protect maternal life or health. ${ }^{19}$

11. Id. at 731 .

12. Id. at 725. But cf. note 117 infra.

13. See pp. 925-26 infra.

14. See $93 \mathrm{~S}$. Ct. at 732. But see note 117 infra.

15. $93 \mathrm{~S}$. C. at 732 . But see note 117 infra.

16. $93 \mathrm{~S}$. Ct. at 732 .

17. This, the Court tells us, is somewhere between the twenty-fourth and twenty-eighth weeks. Id. at 730. But cf. p. 924 infra.

18. See p. 924 infra.

19. $93 \mathrm{~S}$. Ct. at 732. (Thus the statutes of most states must be unconstitutional exen as applied to the final trimester, since they permit abortion only for the purpose of saving the mother's life. See id. at 709.) This holding-that even after viability the mother's life or health (which presumably is to be defined very broadly indeed, so as to include what many might regard as the mother's convenience, see $93 \mathrm{~S}$. C. at 755 (Burger, C.J., concurring)); United States v. Vuitch, 402 U.S. 62 (1971), must, as a matter of constitutional law, take precedence over what the Court scems prepared to grant at this point has become the fetus's life, see p. 924 infra-seems to me at least as controversial as its hold. ing respecting the period prior to viability. (Typically, of coursc, one is not privileged even statutorily, let alone constitutionally, to take another's life in order to save his own life, much less his health.) Since, however, the Court does not see fit to defend this aspect of its decision at all, there is not a great deal that can be said by may of criticism. 
A number of fairly standard criticisms can be made of Roe. A plausible narrower basis of decision, that of vagueness, is brushed aside in the rush toward broader ground. ${ }^{20}$ The opinion strikes the reader initially as a sort of guidebook, addressing questions not before the Court and drawing lines with an apparent precision one generally associates with a commissioner's regulations. ${ }^{21}$ On closer examination, however, the precision proves largely illusory. Confusing signals are emitted, particularly with respect to the nature of the doctor's responsibilities ${ }^{22}$ and the permissible scope of health regulations after the first trimester. ${ }^{23}$ The Court seems, moreover, to get carried away on the subject of remedies: Even assuming the case can be made for an unusually protected constitutional right to an abortion, it hardly seems necessary to have banned during the first trimester all state regulation of the conditions under which abortions can be performed. ${ }^{24}$

By terming such criticisms "standard," I do not mean to suggest they are unimportant, for they are not. But if they were all that was wrong with Roe, it would not merit special comment. ${ }^{25}$

20. The Court's theory seems to be that narrow grounds need not be considercd when there is a broad one that will do the trick: "This conclusion makes it unnecessary for us to consider the additional challenge to the Texas statute asserted on grounds of vagueness." $93 \mathrm{~S}$. Ct. at 732 . Compare id. at $710 \mathrm{n} .3,710-11$; Doc v. Bolton, $93 \mathrm{~S}$. Ct. at 747; Roe v. Wade, 314 F. Supp. 1217, 1223 (N.D. Tex. 1970); cases cited 93 S. Ct. at 727; and United States v. Vuitch, 402 U.S. 62 (1971), bearing in mind that the Suprence Court lacks jurisdiction to "construe" a state statute so as to save it from the vice of vagueness.

21. See also Doe v. Bolton, 93 S. Ct. 739 (1973).

22. Apparently doctors are expected, or at least can be required despite the decisions, to exercise their best "medical" or "clinical" judgment (and presumably can be prosecuted if they perform abortions conflicting with that judgment). $93 \mathrm{~S}$. $\mathrm{Ct}$. at 747,751 . But cf. United States v. Vuitch, 402 U.S. 62, 97 (Stewart, J., dissenting in part). But if it is un: constitutional to limit the justifications for an abortion to considerations of maternil life and health, what kind of "medical" judgment does the Court have in mind? See Stone, Abortion and the Supreme Court, MODERN MEDICINE (forthcoming 1973): "[T]herc arc no clear medical indications for abortion in the vast majority of cases. Where there are no indications, there is no room for clinical judgment."

23. Compare $93 \mathrm{~S}$. Ct. at 732 with id. at 748-51. An additional element of confusion may have been injected by Justice Douglas's indication in his concurrence that "quick. ening" is the point at which the interest in protecting the fetus becomes compelling. Idl. at 759. But see id. at 730, where the Court distinguishes quickening from viability and holds the latter to be the crucial point. See also id. at 732; p. 924 infra.

24. The state can require that the abortion be performed by a doctor, but that is all. But see note 117 infra. Even after the first trimester, the limits on state regulation of the conditions under which an abortion can be performed are extremely stringent. See Doe v. Bolton, 93 S. Ct. 739 (1973).

25. With respect to the capital punishment litigation too, the Court rejected a narrow ground of invalidation one term only to come back with a coup de main the next. Compare MIcGautha v. California, 402 U.S. 183 (1971) with Furman v. Gcorgia, 408 U.S. 238 (1972). Miranda v. Arizona, 384 U.S. 436 (1966), has something of a "guidebook" quality about it. See Dershowitz \& Ely, Harris v. New York: Some Anxious Observations on the Candor and Logic of the Emerging Nixon Majority, 80 YALE L.J. 1198, 1210 (1971). United States v. Wade, 388 U.S. 218 (1967), to take but one example, has always struck 
Let us not underestimate what is at stake: Having an unwanted child can go a long way toward ruining a woman's life. ${ }^{203}$ And at bottom Roe signals the Court's judgment that this result cannot be justified by any good that anti-abortion legislation accomplishes. This surely is an understandable conclusion-indeed it is one with which I agree $2-$ but ordinarily the Court claims no mandate to second-guess legislative balances, at least not when the Constitution has designated neither of the values in conflict as entitled to special protection. ${ }^{\text {s }}$ But even assuming it would be a good idea for the Court to assume this function, Roe seems a curious place to have begun. Laws prohibiting the use of "soft" drugs or, even more obviously, homosexual acts between consenting adults can stunt "the preferred life styles" 28 of those against whom enforcement is threatened in very serious ways. It is clear such acts harm no one besides the participants, and indeed the case that the participants are harmed is a rather shaky one. ${ }^{30}$ Yet such laws survive, ${ }^{31}$ on the theory that there exists a societal consensus that the behavior involved is revolting or at any rate immoral. ${ }^{32}$ Of course the consensus is not universal but it is sufficient, and this is what is counted

me as a case where the Court, starting from the entircly valid realization that trials cannot be fair if lineups are not, went a bit far in limiting the appropriate remedies. And of course many opinions have emitted confusing signals respecting what is henceforth permissible. See, e.g., pp. 929-30 infra.

26. The child may not fare so well either. Of course the Court requires of the mother neither sort of showing, though it may be hoping the doctors will do so. But $\mathrm{cf}$. note 22 supra.

It is also probably the case, although this is the sort of issue where reliable statisties and comparisons are largely unobtainable, that a number of women have died from illegal abortions who would have lived had they been able to secure legal abortions. It is a strange argument for the unconstitutionality of a law that those who evade it suffer, but it is one that must nevertheless be weighed in the balance as a cost of antiabortion legislation. The Court does not mention it, however; and given the severe restrictions it places on state regulation of the conditions under which an abortion can be performed, it apparently did not appreciably inform its judgment.

27. See pp. 926-27 infra.

28. See pp. 926-37 infra. Even where the Constitution does single out one of the values for special protection, the Court has shown an increasing tendency to avoid balancing, or at least to talk as though it were. See Brandenburg y: Ohio, 395 U.S. 444 (1969). See also United States v. Robel, 389 U.S. 258, $268 \mathrm{n.20}$ (1967); but sec Note, Less Drastic Means and the First Amendment, 78 YALE L.J. 404, $407-68$ (1909). Sec alsa United States v. O'Brien, 391 U.S. 367, 376-77 (1968); but cf. Ely, Legislative and Administrativ'e Mlotivation in Constitutional Law, 79 YALE L.J. 1205, 1340-41 (1970).

29. $93 \mathrm{~S}$. Ct. at 759 (Douglas, J., concurring).

30. The claim that the participants are injuring their health secms at least as plausible respecting abortion. Cf. note $117 \mathrm{mfra}$. To the cxtent that the use of soft drugs and homo. sexual activities interfere with the lives of those other than the participants, those in. terferences can be dealt with discretely.

31. Cf. Poe v. Ullman, 367 U.S. 497, $551-53$ (1961), (Harlan, J., dissenting), quoted in part in Griswold v. Connecticut, 38I U.S. 479 , 499 (1965) (Goldberg, J., concurring), distinguishing laws proscribing homosexual acts (even those perforned in the home) as not involving the "right" at stake in those cases.

32. See, e.g., Poe v. Ullman, 367 U.S. 497, 545-46 (Harlan, J., dissenting). 
crucial, to get the laws passed and keep them on the books. Whether anti-abortion legislation cramps the life style of an unwilling mother more significantly than anti-homosexuality legislation cramps the life style of a homosexual is a close question. But even granting that it does, the other side of the balance looks very different. For there is more than simple societal revulsion to support legislation restricting abortion: ${ }^{33}$ Abortion ends (or if it makes a difference, prevents) the life of a human being other than the one making the choice.

The Court's response here is simply not adequate. It agrees, indeed it holds, that after the point of viability (a concept it fails to note will become even less clear than it is now as the technology of birth continues to develop ${ }^{34}$ ) the interest in protecting the fetus is compelling. ${ }^{35}$ Exactly why that is the magic moment is not made clear: Viability, as the Court defines it, ${ }^{36}$ is achieved some six to twelve weeks after quickening. ${ }^{37}$ (Quickening is the point at which the fetus begins discernibly to move independently of the mother ${ }^{38}$ and the point that has historically been deemed crucial-to the extent any point between conception and birth has been focused on. $\left.{ }^{39}\right)$ But no, it is viability that is constitutionally critical: the Court's defense seems to mistake a definition for a syllogism.

With respect to the State's important and legitimate interest in potential life, the "compelling" point is at viability. This is so because the fetus then presumably has the capacity of meaningful life outside the mother's womb. ${ }^{40}$

With regard to why the state cannot consider this "important and legitimate interest" prior to viability, the opinion is even less sntis-

33. Nor is the Court's conclusion that early abortion does not present scrious phys. ical risk to the woman involved shared by all doctors. Cf. note 117 infra.

34 . It defines viability so as not to exclude the possibility of artificial support, 93 S. Ct. at 730 , and later indicates its awareness of the continuing development of arti. ficial wombs. Id. at 731. It gives no sign of having considered the implications of that combination for the trimester program the Constitution is held to mandate, howcver.

35. Albeit not so compelling that a state is permitted to honor it at the expense of the mother's health. See note 19 supra.

36. Note 17 supra.

37. See $93 \mathrm{~S}$. Ct. at 716 .

38. Id.

39. Id. at $716-20$.

40. Id. at 732. See also id. at 730:

Physicians and their scientific colleagues have regarded [quickening] with less in. terest and have tended to focus either upon conception or upon live birth or upon the interim point at which the fetus becomes "viable," ....

The relevance of this observation is not explained. It is, moreover, of questionable validity:

This line is drawn beyond quickening, beyond the point where any religion has assumed that life begins, beyond the time when abortion is a simple procedure, and beyond the point when most physicians and nurses will feel the procedure is victim. less. It is also beyond the point which would have satisfied many who, like myself, were long term supporters of the right to abortion.

Stone, supra note 22. 
factory. The discussion begins sensibly enough: The interest asserted is not necessarily tied to the question whether the fetus is "alive," for whether or not one calls it a living being, it is an entity with the potential for (and indeed the likelihood of) life. ${ }^{41}$ But all of arguable relevance that follows ${ }^{\mathbf{2}}$ are arguments that fetuses (a) are not recognized as "persons in the whole sense" by legal doctrine generally"3 and (b) are not "persons" proterted by the Fourteenth Amendment."4

To the extent they are not entirely inconclusive, the bodies of doctrine to which the Court adverts respecting the protection of fetuses under general legal doctrine tend to undercut rather than support its conclusion.45 And the argument that fetuses (unlike, say, corporations) are not "persons" under the Fourteenth Amendment fares little better. The Court notes that most constitutional clauses using the word "persons"-such as the one outlining the qualifications for the Presidency-appear to have been drafted with postnatal beings in mind. (It might have added that most of them were plainly drafted with

41. Logically, of course, a legitimate state interest in this area need not stand or fall on acceptance of the belief that life begins at conception or at some other point prior to live birth. In assessing the State's interest, recognition may be given to the less rigid claim that as long as at least potential life is involved, the State may assert interests beyond the protection of the pregnant woman alone.

$93 \mathrm{~S}$. Ct. at 725. See also id. at 730:

We need not resolve the difficult question of when life begins. When those trained in the respective disciplines of medicine, philosophy, and theology are unable to ar. rive at any consensus, the judiciary, at this point [sic] in the deiclopment of man's knowledge, is not in a position to speculate as to the answer.

The Texas statute, like those of many states, had declared fetuses to be living beings. See id. at 709 n.1, 710 n.3; cf. id. at 721, 723 n.40, 729 n.55.

42. The opinion does contain a lengthy survey of "historical attitudes" toward abortion, culminating in a discussion of the positions of the American ifedical Association, the American Public Health Association, and the American Bar Association. Id. at 715.24. (The discussion's high point is probably reached where the Court explains away the Hippocratic Oath's prohibition of abortion on the grounds that Hippocrates was a Pythagorean, and Pythagoreans were a minority. Id. at 715-16.) The Coturt does not seem en. tirely clear as to what this discussion has to do with the legal argument, id. at 709, 715, and the reader is left in much the same quandary. It surely does not seem to support the Court's position, unless a record of serious historical and contemporary dispute is somehow thought to generate a constitutional mandate.

43. Id. at 731 .

44. Id. at $728-30$.

45. [T] he traditional rule of tort law had denied recover' for prenatal injuries even though the child was born alive. That rule has been changed in almost every jurisdiction. In most States recovery is said to be permitted only if the fetus was viable, or at least quick, when the injuries were sustained, though few courts have squarely so held. In a recent development, generally opposed by the commentators, some States permit the parents of a stillbom child to maintain an action for wrongful death because of prenatal injuries. Such an action, howerer, would appear to be one to vindicate the parents' interest and is thus consistent with the view that the fetus, at most, represents only the potentiality of life. Similarly, unborn chiluren have been recognized as acquiring rights or interests by way of inheritance or other devolution of property, and have been represented by guardians od litem. Perfection of the interests involved, again, has generally been contingent upon live birth. In short, the unborn have never been recognized in the law as persons in the whole sense.

Id. at 731 (footnotes omitted). See also, e.g., W. Prossen, Haxpeoor of THE LAw of Tonts 355 (3d ed. 1964). 
adults in mind, but I suppose that wouldn't have helped.) In addition, "the appellee conceded on reargument that no case can be cited that holds that a fetus is a person within the meaning of the Fourteenth Amendment." ${ }^{\prime 6}$ (The other legal contexts in which the question could have arisen are not enumerated.)

The canons of construction employed here are perhaps most intriguing when they are contrasted with those invoked to derive the constitutional right to an abortion. ${ }^{47} \mathrm{But}$ in any event, the argument that fetuses lack constitutional rights is simply irrelevant. For it has never been held or even asserted that the state interest needed to justify forcing a person to refrain from an activity, whether or not that activity is constitutionally protected, must implicate either the life or the constitutional rights of another person. ${ }^{48}$ Dogs are not "persons in the whole sense" nor have they constitutional rights, but that does not mean the state cannot prohibit killing them: It does not even mean the state cannot prohibit killing them in the exercise of the First Amendment right of political protest. Come to think of it, draft cards aren't persons either. ${ }^{40}$

Thus even assuming the Court ought generally to get into the business of second-guessing legislative balances, it has picked a strange case with which to begin. Its purported evaluation of the balance that produced anti-abortion legislation simply does not meet the issue: That the life plans of the mother must, not simply may, prevail over the state's desire to protect the fetus simply does not follow from the judgment that the fetus is not a person. Beyond all that, however, the Court has no business getting into that business.

\section{III}

Were I a legislator I would vote for a statute very much like the one the Court ends up drafting. ${ }^{50} \mathrm{I}$ hope this reaction reflects more

46. Id. at 728-29 (footnote omitted).

47. See pp. $928-33$ infra.

48. Indeed it is difficult to think of a single instance where the justification given for upholding a governmental limitation of a protected right has involved the consti. tutional rights of others. A "free press-fair trial" situation might provide the basis for such an order, but thus far the Court has refused to approve one. See Ely, Trial by Newspaper \& Its Cures, ENCOUNTER, March 1967, at 80-92.

In the Court's defense it should be noted that it errs in the other direction as well, by suggesting that if a fetus were a person protected by the Fourtcenth Amendment, it would necessarily follow that appellants would lose. $93 \mathrm{~S}$. Ct. at 728 . Yet in fact all that would thereby be established is that one right granted special protection by the Four. teenth Amendment was in conflict with what the Court felt was another; it would not tell us which must prevail.

49. See United States v. O'Brien, 391 U.S. 367, 376-77 (1968). And if you don't like that example, substitute post offices for draft cards.

50. I would, however, omit the serious restrictions the Court puts on state health regulation of the conditions under which an abortion can be performed, and give 
than the psychological phenomenon that keeps bombardiers sane-the fact that it is somehow easier to "terminate" those you cannot seeand am inclined to think it does: that the mother, unlike the unborn child, has begun to imagine a future for herself strikes me as morally quite significant. But God knows I'm not happy with that resolution. Abortion is too much like infanticide on the one hand, and too much like contraception on the other, to leave one comfortable with any answer; and the moral issue it poses is as fiendish as any philosopher's hypothetical. 51

Of course, the Court often resolves difficult moral questions, and difficult questions yield controversial answers. I doubt, for example, that most people would agree that letting a drug peddler go unapprehended is morally preferable to letting the police kick down his door without probable cause. The difference, of course, is that the Constitution, which legitimates and theoretically controls judicial intervention, has some rather pointed things to say about this choice. There will of course be difficult questions about the applicability of its language to specific facts, but at least the document's special concern with one of the values in conflict is manifest. It simply says nothing, clear or fuzzy, about abortion. ${ }^{52}$

The matter cannot end there, however. The Burger Court, like the Warren Court before it, has been especially solicitous of the right to travel from state to state, demanding a compelling state interest if it is to be inhibited. ${ }^{53}$ Yet nowhere in the Constitution is such a right mentioned. It is, however, as clear as such things can be that this right was one the framers intended to protect, most specificallyw by the Privileges and Immunities Clause of Article IV. ${ }^{\text {50 }}$ The right is, moreover, plausibly inferable from the system of government, and the citizen's role therein, contemplated by the Constitution. ${ }^{30}$ The Court

scrious thought-though the practical difference here is not likely to be great-to placing the critical line at quickening rather than viability. See note 40 supro.

51. Some of us who fought for the right to abortion did so with a divided spirit.

We have always felt that the decision to abort was a human tragedy to be accepted only because an unwanted pregnancy was cren more tragic.

Stone, supra note 22.

52. Of course the opportunity to have an abortion should be considered part of the "liberty" protected by the Fourteenth Amendment. See p. 935 infra.

53. See, e.g., Dunn v. Blumstein, 405 U.S. 330 (1972); Shapiro v. Thompson, 394 U.S. 618 (1969).

54. See also Edwards v. California, 314 U.S. 160 (1911).

55. See United States v. Whecler, 254 U.S. 281, 294 (1920): Slaughterhouse Cases, 83 U.S. (16 Wall.) 36, 75 (1872); U.S. Akrs. CoNfEv. art. IV; 3 M. FARktid, TuE ReconuS of the Federal Convention of 1787, at 112 (1911); cf. Tue Fenenst.1st, No. 42, at 307 (W'right cd. 1961).

56. See Crandall v. Nevada, 73 U.S. (G Wall.) 35 (1867); C. BLAch, STructune AND Relationship IN CoNsmrutional Law (1969). The Court seems to regard the opportunity to travel outside the United States as merely an aspect of the "liberty" that under the Fifth and Fourteenth Amendments cannot be denied without due process. See Zemel v. Rusk, 381 U.S. 1, 14 (1965). Cf. p. 935 infra. 
in Roe suggests an inference of neither sort-from the intent of the framers, ${ }^{57}$ or from the governmental system contemplated by the Constitution-in support of the constitutional right to an abortion.

What the Court does assert is that there is a general right of privacy granted special protection-that is, protection above and beyond the baseline requirement of "rationality"-by the Fourteenth Amendment, ${ }^{58}$ and that that right "is broad enough to encompass" the right to an abortion. The general right of privacy is inferred, as it was in Griswold v. Connecticut, 50 from various provisions of the Bill of Rights manifesting a concern with privacy, notably the Fourth Amendment's guarantee against unreasonable searches, the Fifth Amendment's privilege against self-incrimination, and the right, inferred from the First Amendment, to keep one's political associations secret..$^{00}$

One possible response is that all this proves is that the things explicitly mentioned are forbidden, if indeed it does not actually demonstrate a disposition not to enshrine anything that might be called a general right of privacy. ${ }^{61}$ In fact the Court takes this view when it suits its purposes. (On the same day it decided Roe, the Court held that a showing of reasonableness was not needed to force someone to provide a grand jury with a voice exemplar, reasoning that the Fifth Amendment was not implicated because the evidence was not "testi-

57. Abortions had, of course, been performed, and intermittently proscribed, for centuries prior to the framing of the Constitution. That alone, however, necd not be dispositive. See p. 929 infra \& note 97 infra.

58. The Court does not seem entirely certain about which provision protects the right to privacy and its included right to an abortion.

Appellant would discover this right in the concept of personal "liberty" cmbodicd

in the Fourteenth Amendment's Due Process Clause; or in personal, marital, familial, and sexual privacy said to be protected by the Bill of Rights or its penumbras ... or among those rights reserved to the people by the Ninth Amendment . . . .

$93 \mathrm{~S}$. Ct. at 715.

This right of privacy, whether it be founded in the Fourteenth Amendment's concept of personal liberty and restrictions upon state action, as we fecl it is, or, as the District Court determined, in the Ninth Amendment's reservation of rights 10 the people, is broad enough to encompass a woman's decision whether or not to terminate her pregnancy.

Id. at 727. This inability to pigeonhole confidently the right involved is not important in and of itself. It might, however, have alerted the Court to what is an important question: whether the Constitution speaks to the matter at all.

59. 381 U.S. 479 (1965).

60. See NAACP v. Alabama, 357 U.S. 449 (1958), relied on in Griswold, 381 U.S. at 489. The Roe Court's reference to Justice Goldberg's concurrence in Griswold for the propo. sition that "the roots of" the right of privacy can be found in the Ninth Amendment, $93 \mathrm{~S}$. Ct. at 726 , misconceives the use the earlicr opinion made of that Amendment. Sea 381 U.S. at $492-93$. A reference to "the penumbras of the Bill of Rights," 93 S. Ct. at 726 , can have no content independent of a description of some general value or values inferable from the provisions involved (and therefore assignable to their pentumbras). See San Antonio Independent School Dist. v. Rodriguez, 41 U.S.L.W. 4407, 4438 (U.S. March 21, 1973) (Marshall, J., dissenting); pp. 929.30 infra.

61. See Katz v. United States, 389 U.S. 347, 364 (1967) (Black, J., dissenting); Griswold v. Connecticut, 381 U.S. 479, 529 (Stewart, J., dissenting). 
monial" and that the Fourth Amendment did not apply because there was no "seizure." 62 ) But this approach is unduly crabbed. Surely the Court is entitled, indeed I think it is obligated, to seek out the sorts of evils the framers meant to combat and to move against their twentieth century counterparts. ${ }^{63}$

Thus it seems to me entirely proper to infer a general right of privacy, so long as some care is taken in defining the sort of right the inference will support. Those aspects of the First, Fourth and Fifth Amendments to which the Court refers all limit the ways in which, and the circumstances under which, the government can go about gathering information about a person he would rather it did not have. ${ }^{64}$ Katz $v$. United States, ${ }^{05}$ limiting governmental tapping of telephones, may not involve what the framers would have called a "search," but it plainly involves this general concern with privacy. ${ }^{\circ 0}$ Griswold is a long step, even a leap, beyond this, but at least the connection is discernible. Had it been a case that purported to discover in the Constitution a "right to contraception," it would have been Roe's strongest precedent. ${ }^{67}$ But the Court in Roe gives no evidence of so regarding ${ }^{i t},{ }^{68}$ and rightly not. ${ }^{69}$ Commentators tend to forget, though the Court

62. United States v. Dionisio, 93 S. Ct. 764 (1973). See also United States v. Mara, 93 S. Ct. 774 (1973) (handwriting exemplars), also decided the same day as $R \circ e$, and Couch v. United States, $93 \mathrm{~S}$. Ct. 611 (1973) (finding no privacy interest in records a taxpayer had turned over to her accountant) decided thirtcen dass carlicr.

63. [T] he proper scope of [a constitutional provision], and its relevance to con. temporary problems, must ultimately be sought by attempting to discem the rea-

sons for its inclusion in the Constitution, and the evils it was designed to eliminate.

United States v. Brown, 381 U.S. 437,442 (1965). See also Wecms v. United States, 217 U.S. 349, 373 (1910); Reich, Mr. Justice Black and the Living Constitution, io Fins. L. REv. 673 (1963); Note, The Bounds of Legislative Specification: A Suggested Approach to the Bill of Attainder Clause, 72 YAL.E L.J. 330 (1962).

64. Cf. Fried, Privacy, 77 YALE L.J. 475 (1968). The Third Amendment, mentioned in Griswold though not in Roe, surely has this aspect to it as well, though it probably grew in even larger measure out of a general concern with the pervasiveness of military power.

65. 389 U.S. 347 (1967).

66. Cf. Schmerber v. California, 384 U.S. 757 (1966).

67. Contraception and at least early abortion obviously have much in common. Sce Stone, supra note 22.

68. The Roe opinion does not rely on the obvious contraception-abortion comparison and indeed gives no sign that it finds Grisuold stronger precedent than a number of other cases. See $93 \mathrm{~S}$. Ct. at 726-27; note 79 infra. In fact it secms to go out of its way to characterize Griswold and Eisenstadt v. Baird, 405 U.S. 438 (1972), as cases concerned with the privacy of the bedroom. See $93 \mathrm{~S}$. Ct. at 730; note 79 infra. It is true that in Eisenstadt the Court at one point characterized Grisu'old as protecting the "decision whether to bear and beget a child," 405 U.S. at 453 , but it also, mysteriously in light of that characterization, pointedly refused to decide whether the carlier case extended beyond use, to the distribution of contraceptives. Id. at 452-33. Nor is there any possibility the refusal to extend Griswold in this way was ill-considered; such an extension would have obviated the Eisenstadt Court's obviously strained performance respecting the Equal Protection Clause.

69. Admittedly the Griswold opinion is vague and openended, but the language quoted in the text at note 72 infra seems plainly inconsistent with the view that it is a case not about likely invasions of the privacy of the bedroom but rather direedy enshrining a right to contraception. 
plainly has not, ${ }^{70}$ that the Court in Griswold stressed that it was invalidating only that portion of the Connecticut law that proscribed the use, as opposed to the manufacture, sale, or other distribution of contraceptives. That distinction (which would be silly were the right to contraception being constitutionally enshrined) makes sense if the case is rationalized on the ground that the section of the law whose constitutionality was in issue was such that its enforcement would have been virtually impossible without the most outrageous sort of governmental prying into the privacy of the home. ${ }^{71}$ And this, indeed, is the theory on which the Court appeared rather explicitly to settle:

The present case, then, concerns a relationship lying within the zone of privacy created by several fundamental constitutional guarantees. And it concerns a law which, in forbidding the use of contraceptives rather than regulating their manufacture or sale, seeks to achieve its goals by means having a maximum destructive impact upon that relationship. Such a law cannot stand in light of the familiar principle, so often applied by this Court, that "a governmental purpose to control or prevent activities constitutionally subject to state regulation may not be achieved by means which sweep unnecessarily broadly and thereby invade the area of protected freedoms." NAACP v. Alabama, 377 U.S. 288, 307 . Would we allow the police to search the sacred precincts of marital bedrooms for telltale signs of the use of contraceptives? The very idea is repulsive to the notions of privacy surrounding the marriage relationship. ${ }^{72}$

Thus even assuming (as the Court surely seemed to) that a state can constitutionally seek to minimize or eliminate the circulation and use of contraceptives, Connecticut had acted unconstitutionally by selecting a means, that is a direct ban on use, that would generate intolerably intrusive modes of data-gathering. ${ }^{73}$ No such rationalization is attempted by the Court in Roe-and understandably not, for whatever else may be involved, it is not a case about governmental snooping. ${ }^{74}$

70. See Eisenstadt v. Baird, 405 U.S. 438,443 (1972). Cf. 93 S. Ct. at 730 ; note 79 infra. 71. Stanley v. Georgia, 394 U.S. 557 (1969), cited by the Court in Roe, might also be rationalized on such a theory, cf. $i d$. at 565 , though it reads more like a "pure" First Amendment case concerned with governmental attempts at thought control.

72. 381 U.S. at $485-86$ (emphasis in original).

73. See also Poe v. Ullman, 367 U.S. 497, 548-49, 553-54 (1961) (Harlan, J., dissenting). That the Court in Griswold saw fit to quote Boyd v. United States, 116 U.S. 616, 630 (1886), is also significant. See 381 U.S. at $484-85 \mathrm{n}$.". See also United States v. Gruncwald, 233 F.2d 556, 581-82 (2d Cir. 1956) (Frank, J., dissenting).

The theory suggested in Poe v. Ullman, supra, at 551-52 (Harlan, J., dissenting), ex. tending heightened protection to activities (though it turns out to be some activitics, note 31 supra) customarily performed in the home, is also inapplicable to Roc.

74. Of course in individual cases the government might seek to enforce legislation restricting abortion, as indeed it might seek to enforce any law, in ways that violate the 
The Court reports that some amici curiae argued for an unlimited right to do as one wishes with one's body. This theory holds, for me at any rate, much appeal. However, there would have been serious problems with its invocation in this case. In the first place, more than the mother's own body is involved in a decision to have an abortion; a fetus may not be a "person in the whole sense," but it is certainly" not nothing. ${ }^{75}$ Second, it is difficult to find a basis for thinking that the theory was meant to be given constitutional sanction: Surely it is no part of the "privacy" interest the Bill of Rights suggests. is

$[\mathrm{I}] \mathrm{t}$ is not clear to us that the claim ... that one has an unlimited right to do with one's body as one pleases bears a close relationship to the right of privacy .... it $^{7 \pi}$

Unfortunately, having thus rejected the amici's attempt to define the bounds of the general constitutional right of which the right to an abortion is a part, ${ }^{78}$ on the theory that the general right described has little to do with privacy, the Court provides neither an alternative definition $^{79}$ nor an account of why it thinks privacy is involved. It

Fourth Amendment or otherwise intrude upon the general privacy interest the Bill of Rights suggests. The Court does not suggest, however, that the laws at isste in Roe are in any sense unusually calculated to generate such intrusions.

75. See pp. 925-26 supra.

70. See pp. $929-30$ supra.

77. 93 S. Ct. at 727.

78. The Court's rejection of the "non-paternalism" argument is of course underlined by the health regulations it is prepared to allow during the sccond trimester, before the interest in protecting the fetus is cognizable. See p. 921 supra.

79. The Court does assert that

only personal rights that can be decmed "fundamental" or "implicit in the concept of ordered liberty," Palko v. Connecticut, 302 U.S. 319, 325 (1937), are included in this guarantee of personal privacy. They also make it clear that the right has some cxtension to activities relating to marriage, Loving v. Virginia, 385 U.S. 1, 12 (1967), procreation, Skinner v. Oklahoma, 316 U.S. 535, $541-42$ (1942), contraception, Eisenstadt v. Baird, 405 U.S. $438,453-54$ (1972); id. at 460 , 463.65 (White, J., concurring). family relationships, Prince v. Massachusetts, 321 U.S. 158, 166 (1944), and child rearing and education, pierce v. Society of Sisters, 268 U.S. 510,535 (1925), Mejer v. Nebraska, [262 U.S. 390, 399 (1923)].

$93 \mathrm{~S}$. Ct. at $726-27$. The Palko test was stated and has heretofore been tahen as a definition (of questionable contemporary vitality) of duc process generally, not of privacy. Loving was a case involving explicit racial discrimimation and therefore decidable (and decided) by a rather straightforward application of the Equal I'rotcction Clatuse. See Ely, supra note 28, at 1230. And while the Loving Court did, inexplicably, append a reference to due process, it did not mention privacy. Skimner invalidated the Oklahoma criminal sterilization act's distinction betwcen larcenists and embezlers. Nlthough it too did not allude to privacy, it did suggest it was applying a higher equal protection standard than usual. Why it did so is unclear. "Faced with the possibility of a finding of cruel and unusual punishment and the virtual certainty of invalidation under the clause proscribing ex post facto laws, the state declined to argue the case on the theory that the ... Act was a penal statute, and therefore tried to justify the distinction in "regula. tory" tcrms." Ely, supra, at 1235 n.101. That being so, the state was unable to come up with cven a plausible justification for the distinction. Eisenstadt was a case applying "traditional" equal protection standards, albcit in a less than stisfactory way. See Note, Legislative Purpose, Rationality, and Equal Protection, 82 Yale L.J. 123 (1972). The 
simply announces that the right to privacy "is broad enough to encompass a woman's decision whether or not to terminate her pregnancy." Apparently this conclusion is thought to derive from the passage that immediately follows it:

The detriment that the State would impose upon the pregnant woman by denying this choice altogether is apparent. Specific and direct harm medically diagnosable even in early pregnancy may be involved. Maternity, or additional offspring, may force upon the woman a distressful life and future. Psychological harm may be imminent. Mental and physical health may be taxed by child care. There is also the distress, for all concerned, associated with the unwanted child, and there is the problem of bringing a child into a family already unable, psychologically and otherwise, to care for it. In other cases, as in this one, the additional difficulties and continuing stigma of unwed motherhood may be involved. ${ }^{80}$

All of this is true and ought to be taken very seriously. But it has nothing to do with privacy in the Bill of Rights sense or any other the Constitution suggests. ${ }^{81} \mathrm{I}$ suppose there is nothing to prevent one from using the word "privacy" to mean the freedom to live one's life without governmental interference. But the Court obviously does not so use the term. ${ }^{82}$ Nor could it, for such a right is at stake in every case. Our

passage cited by the Court in Roe reiterated Griswold's conclusion that privacy interests are threatened by a ban on the usc of contraceptives, but declincd to decide whether its rationale should be extended to restrictions on distribution. See p. 9y30 supra. Prince upheld the application of a child labor law to Jehovah's Witness children distributing religious literature. It did, however, reiterate the conclusion of Pierce and Meyer that family relationships are entitled to special protection. Those two cases arc products of "the Lochner era," see pp. 937-43 infra. The vitality of the theory on which they rested has been questioned, Epperson v. Arkansas, 393 U.S. 97, 105.06 (1968), and the Court has attempted to recast them as First Amendment cases. Griswold v. Connecticut, 381 U.S. 479, 482 (1965); cf. loe v. Ullman, 367 U.S. 497, 533.34 (1961) (Harlan, J., dissenting). Even reading the cases cited "for all that they are worth," it is difficult to isolate the "privacy" factor (or any other factor that secms constitutionally relevant) that unites them with each other and with Roe. So the Court scems to admit by indicating that privacy has "some extension" to the activities involved, and so it secms later to grant even more explicitly.

The pregnant woman cannot be isolated in her privacy. She carries an embryo and,

later, a fetus. ... The situation therefore is inherently different from marital in.

timacy, or bedroom possession of obscene material, or marriage, or procreation, or

education, with which Eisenstadt, Griswold, Stanley, Loving, Skinner, Pierce, and

Meyer were respectively concerned.

$93 \mathrm{~S}$. Ct. at 730 .

80. $93 \mathrm{~S}$. Ct. at 727. See also id. at 757 (Douglas, J., concurring).

81. It might be noted that most of the factors enumerated also apply to the inconvenience of having an unwanted two-year-old, or a senile parent, around. Would the Court find the constitutional right of privacy invaded in those situations too? I find it hard to believe it would; even if it did, of course, it would not find a constitutional right to "terminate" the annoyance-presumably because "real" persons are now in. volved. But cf. p. 926 supra \& note 48 supra. But what about ways of removing the annoyance that do not involve "termination"? Can they really be matters of constitil.
tional entitlement?

82. But cf. 93 S. Ct. at 758-59 (Douglas, J., concurring). 
life styles are constantly limited, often seriously, by governmental regulation; and while many of us would prefer less direction, granting that desire the status of a preferred constitutional right would yield a system of "government" virtually unrecognizable to us and only slightly more recognizable to our forefathers. ${ }^{83}$ The Court's observations concerning the serious, life-shaping costs of having a child prove what might to the thoughtless have seemed unprovable: That even though a human life, or a potential human life, hangs in the balance, the moral dilemma abortion poses is so difficult as to be heartbreaking. What they fail to do is even begin to resolve that dilemma so far as our governmental system is concerned by associating either side of the balance with a value inferable from the Constitution.

But perhaps the inquiry should not end even there. In his famous Carolene Products footnote, Justice Stone suggested that the interests to which the Court can responsibly give extraordinary constitutional protection include not only those expressed in the Constitution but also those that are unlikely to receive adequate consideration in the political process, specifically the interests of "discrete and insular minorities" unable to form effective political alliances. ${ }^{8 t}$ There can be little doubt that such considerations have influenced the direction, if only occasionally the rhetoric, of the recent Courts. My repeated efforts to convince my students that sex should be treated as a "suspect classification" have convinced me it is no easy matter to state such considerations in a "principled" way. But passing that problem, Roe is not an appropriate case for their invocation.

Compared with men, very few women sit in our legislatures, a fact I believe should bear some relevance-even without an Equal Rights Amendment-to the appropriate standard of review for legislation that favors men over women. ${ }^{85}$ But no fetuses sit in our legislatures. Of

\footnotetext{
83. Cf. Katz v. United States, 389 U.S. $347,350-51$ (196\%).

84. United States v. Carolene Products Co., 304 U.S. 144, 152 n.4 (1938).

85. This is not the place for a full treatment of the subject, but the general idea is this: Classifications by sex, like classifications by race, differ from the usual clas. sification-to which the traditional "reasonable generalization" standard is properly applied-in that they rest on "we-they" generalizations as opposed to a "they-they" generalization. Take a familiar example of the usual approach. Williamson $v$. Lee Optical Co., 348 U.S. 483 (1955). Of course few Jegislators are opticians. But few are optometrists either. Thus while a decision to distinguish opticians from optometrists will incorporate a stereotypical comparison of two classes of people, it is a comparison of two "they" stereotypes, viz. "They [opticians] are generally inferior to or not so well qualificd as they [optometrists] are in the following respect(s), which we find sufficient to justify the classification: ...." Howerer, legislators traditionally have not only not been black (or female); they have been white (and malc). A decision to distinguish blacks from whites (or women from men) will therefore have its roots in a comparison betwicen a "we" stereotype and a "they" stereotype, viz. "They [blacks or women] are generally" inferior to or not so well qualified as we [whites or men] are in the following respect(s),
which we find sufficient to justify the classification: ...."
} 
course they have their champions, but so have women. The two interests have clashed repeatedly in the political arena, and had continued to do so up to the date of the opinion, generating quite a wide variety of accommodations. ${ }^{80}$ By the Court's lights virtually all of the legislative accommodations had unduly favored fetuses; by its definition of victory, women had lost. Yet in every legislative balance one of the competing interests loses to some extent; indeed usually, as here, they both do. On some occasions the Constitution throws its weight on the side of one of them, indicating the balance must be restruck. And on others-and this is Justice Stone's suggestion-it is at least arguable that, constitutional directive or not, the Court should throw its weight on the side of a minority demanding in court more than it was able to achieve politically. But even assuming this suggestion can be given principled content, it was clearly intended and should be reserved for those interests which, as compared with the interests to which they have been subordinated, constitute minorities unusually incapable of protecting themselves. ${ }^{87}$ Compared with men, women may constitute

The choice between classifying on the basis of a comparative generalization and attempting to come up with a more discriminating formula always involves balancing the increase in fairness which greater individualization will produce against the added costs it will entail. It is no startling psychological insight, however, that most of us are delighted to hear and prone to accept comparative characterizations of groups that sug. gest that the groups to which we belong are in some way superior to others. (I would be inclined to exclude most situations where the "we's" used to be "they's," cf. Ferguson v. Skrupa, 372 U.S. 726 (1963), and would therefore agrec that the unchangeability of the distinguishing characteristic is indeed relevant, though it is only part of the story.) The danger is therefore greater in we-they situations that we will overestimate the validity of the proposed stereotypical classification by seizing upon the positive myths about our own class and the negative myths about theirs-or indeed the realities respecting some or most members of the two classes-and too readily assuming that virtually the entire membership of the two classes fit the stereotypes and therefore that not many of "them" will be unfairly deprived, nor many of "us" unfairly benefitted, by the proposed classification. In short, I trust your generalizations about the differences between my gang and Wilfred's more than $I$ do your generalizations about the differences between my gang and yours.

Of course most judges, like most legislators, are white males, and there is no particular reason to suppose they are any more immune to the conscious and unconscious temptations that inhere in we-they generalizations. Obviously the factors mentioned can distort the evaluation of a classification fully as much as they can distort its formation. But all this is only to suggest that the Court has chosen the right course in reviewing classifications it has decided are suspicious-a course not of restriking or secondguessing the legislative cost-benefit balance but rather of demanding a congruence bctween the classification and its goal as perfect as practicable. When in a given situation you can't be trusted to generalize and I can't be trusted to generalize, the answer is not to generalize-so long as a bearable alternative exists. And here, the Court has recognized, one does-the alternative of forcing the system to absorb the additional cost that case by case determinations of qualification will entail. Legislatures incur this cost voluntarily in a great many situations, and courts have on other occasions forced them to do so where constitutionally protected interests will be threatened by an imperfectly fitting classification. The unusual dangers of distortion that inhere in a we-they process of comparative generalization, the Court seems to have been telling us in the racial clas. sification cases, also demand that we bear the increased cost of individual justice.

86. See 93 S. Ct. at 708-10, 720, 723-24, 742-43, 752-55.

87. If the mere fact that the classification in issue disadvantages a minority whose viewpoint was not appreciated by a majority of the legislature that enacted it were sufficient to render it suspect, all classifications would be suspect. 
such a "minority"; compared with the unborn, they do not. ${ }^{88}$ I'm not sure I'd know a discrete and insular minority if I saw one, but confronted with a multiple choice question requiring me to designate (a) women or (b) fetuses as one, I'd expect no credit for the former answer. ${ }^{89}$

Of course a woman's freedom to choose an abortion is part of the "liberty" the Fourteenth Amendment says shall not be denied without due process of law, as indeed is anyone's freedom to do what he wants. But "due process" generally guarantees only that the inhibition be procedurally fair and that it have some "rational" connection-though plausible is probably a better word ${ }^{90}$-with a permissible governmental goal. ${ }^{91}$ What is unusual about $R o e$ is that the liberty involved is accorded a far more stringent protection, so stringent that a desire to preserve the fetus's existence is unable to overcome it-a protection more stringent, I think it fair to say, than that the present Court accords the freedom of the press explicitly guaranteed by the First Amendment. ${ }^{92}$ What is frightening about $R o e$ is that this super-protected right is not inferable from the language of the Constitution,

88. Even if the case could be made that abortion is an issue that pits the interests of men against those of women, that alone would not bring it within a theory that renders suspect classifications based on generalizations about the characteristics of men and women. And even if there were some way to expand the theory (and I confess I cannot see what judicial remedy would be appropriate were the theory so expanded, but see note 85 supra, third paragraph) to cover all "interests of men versus interests of women" situations, it will take some proving to establish that this is one:

[D] ecisions in society are made by those who have power and not by those who

have rights. Husbands and boy friends may in the end wield the power and make the abortion decision. Many women may be forced to have abortions not because

it is their right, but because they are forced by egocentric men to submit to this procedure to avoid an unwanted inconvenience to men.

Stone, supra note 22.

89. It might be suggested that legislation restricting abortion had been kept on the books by the efforts of an intense minority and did not represent the will of most legislative majorities. Though I am aware of no basis for inferring this is any truer here than it is with respect to other sorts of legislation, see also note 86 supra, it is the sort of claim that is hard to disprove. (The phenomenon described at pp. 946-47 infra, one of relief that the issue has been taken out of the political arena, is a very different matter.) In any event it is not the Court's job to repeal such legislation. In the first place there is nothing unusual, and I was not aware there was anything wrong, with an intense minority's compromising on issues about which it feels less strongly in order to garner support on those it cares most about. Moreover, precisely because the claims involved are difficult to evaluate, I would not want to entrust to the judiciary authority to guess about them-certainly not under the guise of enforcing the Constitution. Leaving aside the arguable case of a law that has been neither legislatively considered nor enforced for decades, see A. Bickel, The Least Dangerous Branch 143-56 (1962), the Court should rest its declaration of unconstitutionality, if any, on more than a guess about how widespread and intense the support for the law "really" is.

90. The claimed connection is often empirical, causal or normative. About all that does not seem to become involved is formal logic. See p. 941 infra; Ely, supra note 28 , at $1237 \times 49$.

91. Even this statement of the demands of "substantive due process" is too strong for many Justices and commentators, who deny that any such doctrine should exist. See, e.g., pp. 937-38 infra.

92. See Branzburg v. Hayes, 408 U.S. 665 (1972). 
the framers' thinking respecting the specific problem in issue, any general value derivable from the provisions they included, ${ }^{93}$ or the nation's governmental structure. Nor is it explainable in terms of the unusual political impotence of the group judicially protected visà-vis the interest that legislatively prevailed over it. ${ }^{94}$ And that, I believe-the predictable" early reaction to Roe notwithstanding ("more of the same Warren-type activism"96)-is a charge that can responsibly be leveled at no other decision of the past twenty years. ${ }^{97}$ At times the

93. See pp. 928-33 supra. Necessarily, a claim of this sort can never be established beyond doubt; one can only proceed by examining the claims of those values he thinks or others have suggested, are traceable to the Constitution. It is always possible, however, that someone will develop a general theory of entitlements that encompasses a given case and plausibly demonstrate its constitutional connections. It is also possible that had the constitutional right to an abortion been developed as constitutional doctrines usually are-that is incrementally, rather than by the quantum jump of Roe-the connection of the first step with the Constitution, and that of each succeeding step with its predecessor, would have seemed more plausible. I cannot bring myself to believe, however, that any amount of gradualism could serve to make anything approaching the entire inference convincing.

94. The thing about permitting disparity among state laws regulating abortion that $I$ find most troubling is not mentioned by the Court, and that is that some people can afford the fare to a neighboring state and others cannot. Of course this situation prevails with respect to divorce and a host of other sorts of laws as well. I wish someone could develop a theory that would enable the Court to take account of this concern without implying a complete obliteration of the federal system that is so obviously at the heart of the Constitution's plan. I have not been able to do so. See note 87 supra.

95. See pp. $943-45$ infra.

96. See, e.g., Abortion, The NEw Republic, Feb. 10, 1973, at 9; Stone, supra note 22.

97. Of course one can disagree with the lengths to which the inferences have been taken; my point is that the prior decisions, including those that have drawn the most fire, at least started from a value singled out by, or fairly inferable from, the Constitution as entitled to special protection. Whatever one may think of the code of conduct laid down in Miranda v. Arizona, 384 U.S. 436 (1966), the Constitution does talk about the right to counsel and the privilege against self-incrimination. Whatever one may think of the strictness of the scrutiny exercised in Furman v. Georgia, 408 U.S. 238 (1972), the Eighth Amendment surely does indicate in a general way that punishments are to be scrutinized for erratic imposition ("unusual") and severity disproportionate to any good they can be expected to accomplish ("cruel").

Note that the claim in the text has to do with the capacity of the earlier decisions to be rationalized in terms of some value highlighted by the Constitution, not with the skill with which they were in fact rendered. It is now pretty generally recognized, for example, that the various "wealth discrimination" cases could better have been defended in terms of the constitutional attention paid explicitly or implicitly to the "goods" whose distribution was in issue-the right to vote and the assurance of fair judicial procedures. See, e.g., Michelman, Foreword: On Protecting the Poor Through the Fourteenth Amendment, 83 HARv. L. Rev. 7 (1969). Reynolds v. Sims, 377 U.S. 533 (1964), is a badly articulated opinion. Its only response to the argument made by Justice Stewartthat since an equal protection claim was involved, a rational defense of a disparity among the "weights" of votes should suffice-was simply to announce that the goals Justice Stewart had in mind were off limits. See Ely, supra note 28, at 1226-27. But even Justice Stewart could not take the equal protection mold too seriously, for he added he would not approve a plan that permitted "the systematic frustration of the will of a majority of the electorate of the State." Lucas v. Colorado Gen. Assembly, 377 U.S. 713, 753.54 (1964) (footnote omitted). Such a plan, however, could be quite "rational" in terms of the sort of goals Justice Stewart had in mind, goals that in other contexts would count as legitimate. Obviously Justice Stewart was moved to some extent by the notion that a system whereby a minority could perpetuate its control of the government was out of accord with the system of government envisioned by the framers. See also Kramer v. Union Free School District No. 15, 395 U.S. 621, 628 (1969) (Warren, C.J., for the Court). This was what moved the Court too, though much further. And though the Court did 
inferences the Court has drawn from the values the Constitution marks for special protection have been controversial, even shaky, but never before has its sense of an obligation to draw one been so obviously lacking.

\section{IV}

Not in the last thirty-five years at any rate. For, as the received learning has it, this sort of thing did happen before, repeatedly. From its 1905 decision in Lochner v. New York ${ }^{08}$ into the 1930's the Court, frequently though not always under the rubric of "liberty of contract," employed the Due Process Clauses of the Fourteenth and Fifth Amendments to invalidate a good deal of legislation. According to the dissenters at the time and virtually all the commentators since, the Court had simply manufactured a constitutional right out of whole cloth and used it to superimpose its own view of wise social policy on those of the legislatures. So indeed the Court itself came to see the matter, and its reaction was complete:

There was a time when the Due Process Clause was used by this Court to strike down laws which were thought unreasonable, that is, unwise or incompatible with some particular economic or social philosophy. In this manner the Due Process Clause was used, for example, to nullify laws prescribing maximum hours for work in bakeries, Lochner v. New York, 198 U.S. 45 (1905), outlawing

not give the reason, there is one: a fear that by attempting to apply Justice Stewart's "in between" standard it would become embroiled in unsecmly" "political" inquiries into the power alignments prevalent in the various states. See Deutsch, Neutrality, Legitimacy, and the Supreme Court: Some Intersections Betueen Law and Political Science, 20 Stan. L: Rev. 169, $246-47$ (1968); cf. note 89 supra; but cf. Mahan v. Howell, 41 U.S.L.W. 4277 (U.S. Feb. 20, 1973). Though the point is surely debatable, the impulse is understandable, and the fight in Reynolds, like that in Miranda, turns out to be not so much over the underlying values as over the need for a "clean" prophylactic rulc that will keep the courts out of messy factual disputes.

In his concurrence in Roe, Justice Stewart lists ten cases to prove that "the Due Process Clause of the Fourteenth Amendment covers more than those frecdoms explicitly named in the Bill of Rights." $93 \mathrm{~S}$. Ct. at 734. His point is obviously that the freedoms involved were given protection above and bejond the ordinary demand for a "rational" defense and therefore Roe is just more of the same. It is not. Schware $v$. Bd. of Bar Examiners, 353 U.S. 232 (1957); Aptheker v. Secretary of State, 378 U.S. 500 (1961); and Kent v. Dulles, 357 U.S. 116 (1958), are all obviously rationalizable as First Amendment cases and indeed have since been so rationalized. Concerning Schutare, see Griswold v: Connecticut, 381 U.S. 479, 483 (1965); cf. United States v. Brown, 381 U.S. 437. 456 (195j). As to Aptheker and Kent, see Zemel v. Rusk, 38I U.S. 1, 16 (1965): United States v. Brown, 381 U.S. at 456 . Concerning Pierce v. Society of Sisters and Mcjer v. Nebraska, see note 79 supra. As to Shapiro v. Thompson, 394 U.S. 618 (1969), and United States v. Guest, 383 U.S. 745 (1966), see p. 927 supra. W'ith respect to Carrington v. Rash, 380 U.S. 89 (1965), see the preceding paragraph of this footnote and C. BLACr, supra note 56. Concerning Bolling v. Sharpe, 347 U.S. 497 (1954), see note 79 supra; but cf. Linde, Judges, Critics, and the Realist Tradition, 82 YALE L.J. 227, 233.35 (1972). And compare Truax v. Raich, 239 U.S. 33 (1915), with Graham v. Richardson, 403 U.S. 365 (1971), and note 85 supra.

98. 198 U.S. 45 (1905). 
"yellow dog" contracts, Coppage v. Kansas, 236 U.S. 1 (1915), setting minimum wages for women, Adkins $v$. Children's Hospital, 261 U.S. 525 (1923), and fixing the weight of loaves of bread, Jay Burns Baking Co. v. Bryan, 264 U.S. 504 (1924). This intrusion by the judiciary into the realm of legislative value judgments was strongly objected to at the time .... Mr. Justice Holmes said,

"I think the proper course is to recognize that a state legislature can do whatever it sees fit to do unless it is restrained by some express prohibition in the Constitution of the United States or of the State, and that Courts should be careful not to extend such prohibitions beyond their obvious meaning by reading into them conceptions of public policy that the particular Court may happen to entertain."

... The doctrine that prevailed in Lochner, Coppage, Adkins, Burns, and like cases-that due process authorizes courts to hold laws unconstitutional when they believe the legislature has acted unwisely-has long since been discarded. We have returned to the original constitutional proposition that courts do not substitute their social and economic beliefs for the judgment of legislative bodies, who are elected to pass laws. ${ }^{99}$

It may be objected that Lochner et al. protected the "economic rights" of businessmen whereas Roe protects a "human right." It should be noted, however, that not all of the Lochner series involved economic regulation; ${ }^{100}$ that even those that did resist the "big business" stereotype with which the commentators tend to associate them; and that in some of them the employer's "liberty of contract" claim was joined by the employee, who knew that if he had to be employed on the terms set by the law in question, he could not be employed at all.101 This is a predicament that is economic to be sure, but is not without its "human" dimension. Similarly "human" seems the predicament of the appellees in the 1970 case of Dandridge $v$. Williums, ${ }_{1}^{102}$ who challenged the Maryland Welfare Department's practice of limiting AFDC grants to $\$ 250$ regardless of family size or need. Yet in language that remains among its favored points of reference, ${ }^{103}$ the

99. Ferguson v. Skrupa, 372 U.S. 726, $729-30$ (1963) (footnotes omitted). See also Lincoln Federal Labor Union v. Northwestern Iron \& Metal Co., 335 U.S. 525, 533.37 (1949). 100. See Pierce v. Society of Sisters, 268 U.S. 510 (1925); Meyer v. Nebraska, 262 U.S. 390 (1923).

101. E.g., Adkins v. Children's Hospital, 261 U.S. 525, 542.43 (1923). See also Adair v. United States, 208 U.S. 161, 172-73 (1908). Cf. Hammer v. Dagenhart, 247 U.S. 251 (1918). 102. 397 U.S. 471 (1970).

103. See, e.g., San Antonio Independent School Dist. v. Rodriguez, 41 U.S.L.W. 4407, 4417 (U.S. March 21, 1973); Ortwein v. Schwab, 41 U.S.L.W. 3473,3474 (U.S. March 5, 1973); United States v. Kras, 93 S. Ct. 631, 638 (1973). 
Court, speaking through Justice Stewart, ${ }^{104}$ dismissed the complaint as "social and economic" and therefore essentially Lochneresque.

[W]e deal with state regulation in the social and economic field, not affecting freedoms guaranteed by the Bill of Rights. . . . For this Court to approve the invalidation of state economic or social regulation as "overreaching" would be far too reminiscent of an era when the Court thought the Fourteenth Amendment gave it power to strike down state laws "because they may be unwise, improvident, or out of harmony with a particular school of thought." ... That era long ago passed into history. . . .

To be sure, the cases cited .. . have in the main involved state regulation of business or industry. The administration of public welfare assistance, by contrast, involves the most basic economic needs of impoverished human beings. We recognize the dramatically real factual difference between the cited cases and this one, but we can find no basis for applying a different constitutional standard. . . I It is a standard ... that is true to the principle that the Fourteenth Amendment gives the federal courts no power to impose upon the States their views of wise economic or social policy. ${ }^{105}$

It may be, however-at least it is not the sort of claim one can disprove -that the "right to an abortion," or noneconomic rights generally, accord more closely with "this generation's idealization of America"100 than the "rights" asserted in either Lochner or Dandridge. But that attitude, of course, is precisely the point of the Lochner philosophy, which would grant unusual protection to those "rights" that somehow seem most pressing, regardless of whether the Constitution suggests any special solicitude for them. The Constitution has little to say about contract, ${ }^{107}$ less about abortion, and those who would speculate about which the framers would have been more likely to protect may not be pleased with the answer. The Court continues to disavow the philosophy of Lochner: ${ }^{108}$ Yet as Justice Stewart's concurrence admits, it is impossible candidly to regard Roe as the product of anything else. ${ }^{100}$

104. But cf. note 109 infra.

105. 397 U.S. at 48486 .

106. Karst \& Horowitz, Reitman v. Mulkey: A Teleophase of Substantive Equal Prolection, 1967 SUP. CT. Rev. 39, 57-58; cf. 2 L. Pollak, The CoNstitution and tie Surreas Court: A Documentary History 266-67 (1966).

107. But see U.S. Const. art. I, $\$ 10$; Calder v. Bull, 3 U.S. (3 Dall.) 386 (1798).

108. See note 103 supra.

109. $93 \mathrm{~S}$. Ct. at 734. The only "Lochner cra" cases Justice Stewart cites are Mreger and Pierce. It therefore may be he intends to pursue some sort of "cconomic-noncconomic" line in selecting rights entitled to special protection. But sec text at note 105 supra. The general philosophy of constitutional adjudication, however, is the same. See text at notes 106-07 supra. Justice Stewart rather clearly intends his Roe opinion as a repudiation 
That alone should be enough to damn it. Criticism of the Lochner philosophy has been virtually universal and will not be rehearsed here. I would, however, like to suggest briefly that although Lochner and Roe are twins to be sure, they are not identical. While I would hesitate to argue that one is more defensible than the other in terms of judicial style, there are differences in that regard that suggest Roe may turn out to be the more dangerous precedent.

All the "superimposition of the Court's own value choices" talk is, of course, the characterization of others and not the language of Lochner or its progeny. Indeed, those cases did not argue that "liberty of contract" was a preferred constitutional freedom, but rather represented it as merely one among the numerous aspects of "liberty" the Fourteenth Amendment protects, therefore requiring of its inhibitors a "rational" defense.

In our opinion that section $\ldots$ is an invasion of the personal liberty, as well as of the right of property, guaranteed by that Amendment. Such liberty and right embraces the right to make contracts for the purchase of the labor of others and equally the right to make contracts for the sale of one's own labor; each right, however, being subject to the fundamental condition that no contract, whatever its subject matter, can be sustained which the law, upon reasonable grounds, forbids as inconsistent with the public interests or as hurtful to the public order or as detrimental to the common good. ${ }^{110}$

Undoubtedly, the police power of the State may be exerted to protect purchasers from imposition by sale of short weight loaves. ... Constitutional protection having been invoked, it is the duty of the court to determine whether the challenged provision has reasonable relation to the protection of purchasers of bread against fraud by short weights and really tends to accomplish the purpose for which it was enacted.111

of his Griswold dissent, and not simply as an acquiescence in what the Court did in the earlier case. See 93 S. Ct. at 735 .

Having established to his present satisfaction that the Due Process Clause cxtends unusual substantive protection to interests the Constitution nowhere marks as special, but see note 97 supra, he provides no further assistance respecting the difficult (jues. tions before the Court, but rather defers to the Court's "thorough demonstration" that the interests in protecting the mother and preserving the fetus cannot support the legis. lation involved. But see pp. 922-26 supra.

110. Adair v. United States, 208 U.S. 161,172 (1908). See also id. at 174.

111. Jay Burns Baking Co. v. Bryan, 264 U.S. 504, 513 (1924). See also id. at b17; Meyer v. Nebraska, 262 U..S. 390, 399.400, 403 (1923); Adkins v. Children's Hospital, 261 U.S. 525, 529 (1923); Coppage v. Kansas, 236 U.S. 1, 14 (1915); Lochner v. New York, 198 U.S. $45,53,54,56,57$ (1905); id. at 68 (Harlan, J., dissenting). 
Thus the test Lochner and its progeny purported to apply is that which would theoretically control the same questions today: whether a plausible argument can be made that the legislative action furthers some permissible governmental goal. ${ }^{112}$ The trouble, of course, is they misapplied it. Roe, on the other hand, is quite explicit that the right to an abortion is a "fundamental" one, requiring not merely a "rational" defense for its inhibition but rather a "compelling" one.

A second difference between Lochner et al. and Roe has to do with the nature of the legislative judgments being second-guessed. In the main, the "refutations" tendered by the Lochner series were of two sorts. The first took the form of declarations that the goals in terms of which the legislatures' actions were defended were impermissible. Thus, for example, the equalization of unequal bargaining power and the strengthening of the labor movement are simply ends the legislature had no business pursuing, and consequently its actions cannot thereby be justified.113 The second form of "refutation" took the form not of denying the legitimacy of the goal relied on but rather of denying the plausibility of the legislature's empirical judgment that its action would promote that goal.

In our judgment it is not possible in fact to discover the connection between the number of hours a baker may work in the bakery and the healthful quality of the bread made by the workman. ${ }^{114}$

There is no evidence in support of the thought that purchasers have been or are likely to be induced to take a nine and a half or a ten ounce loaf for a pound (16 ounce) loaf, or an eighteen and a half or a 19 ounce loaf for a pound and a half (24 ounce) loaf; and it is contrary to common experience and unreasonable to assume that there could be any danger of such deception. ${ }^{115}$

The Roe opinion's "refutation" of the legislative judgment that antiabortion statutes can be justified in terms of the protection of the fetus takes neither of these forms. The Court grants that protecting the fetus is an "important and legitimate" governmental goal, ${ }^{110}$ and of course

112. But cf. note 91 supra.

113. Coppage v. Kansas, 236 U.S. 1, 16-17, 17-18 (1915). See also Aleyer v. Nebraska, 262 U.S. 390, 403 (1923); Adair v. United States, 208 U.S. 161, 174-75 (1908); Lochner v. New York, 198 U.S. 45, 57-58 (1905).

114. Lochner v. New York, 198 U.S. 45, 62 (1905). See also id. at 57, 58, 59, 64.

115. Jay Burns Baking Co. v. Bryan, 264 U.S. 504, 517 (1924). See also Coppage v. Kansas, 236 U.S. 1, 15-16 (1915).

116. Note 8 supra. 
it does not deny that restricting abortion promotes it. ${ }^{117}$ What it does, instead, is simply announce that that goal is not important enough to sustain the restriction. There is little doubt that judgments of this sort were involved in Lochner et al., ${ }^{118}$ but what the Court said in those cases was not that the legislature had incorrectly balanced two legitimate but competing goals, but rather that the goal it had favored was impermissible or the legislation involved did not really promote it. ${ }^{119}$

Perhaps this is merely a rhetorical difference, but it could prove to be important. Lochner et al. were thoroughly disreputable decisions, but at least they did us the favor of sowing the seeds of their own destruction. To say that the equalization of bargaining power or the fostering of the labor movement is a goal outside the ambit of a "police power" broad enough to forbid all contracts the state legislature can reasonably regard "as inconsistent with the public interests or as hurtful to the public order or as detrimental to the common good"120 is to say something that is, in a word, wrong. ${ }^{121}$ And it is just as obvi-

117. The Lochner approach to factual claims is, however, suggested by the Court's ready acceptance-by way of nullifying the state's health intercst during the first trimester - of the data adduced by appellants and certain amici to the effect that abortions performed during the first trimester are safer than childbirth. $93 \mathrm{~S}$. Ct. at 725 . This is not in fact agreed to by all doctors-the data are of course severcly limited-and the Court's view of the matter is plainly not the only one that is "rational" under the ustual standards. See San Antonio Independent School Dist. v. Rodriguez, 41 U.S.L.W. 4407, 4420 (U.S. March 21, 1973); Eisenstadt v. Baird, 405 U.S. 438, 470 (1972) (Burger, C.J., dissenting):

The actual hazards of introducing a particular foreign substance into the human body are frequently controverted, and I cannot believe the unanimity of expert opinion is a prerequisite to a State's exercise of its police power, no matter what the subject matter of the regulation. Even assuming no present dispute among medical authorities, we cannot ignore that it has become commonplace for a drug or food additive to be universally regarded as harmless on one day and to be condemncd as perilous the next. It is inappropriate for this Court to overrule a legislative clas. sification by relying on the present consensus among leading authorities. The com. mands of the Constitution cannot fluctuate with the shifting tides of scientific opinion. I suppose the Court's defense of its unusual reaction to the scientific data would be that the case is unusual, in that it involves a "fundamental" interest. It should be noted, however, that even a sure sense that abortion during the first trimester is safer than childbirth would serve only to blunt a state's claim that it is, for reasons relating to maternal health, entitled to proscribe abortion; it would not support the inference the Court draws, that regulations designed to make the abortion procedure safer during the first trimester are impermissible. See $93 \mathrm{~S}$. Ct. at 732.

118. Cf. Meyer v. Nebraska, 262 U.S. 390 (1923); Adkins v. Children's Hospital, 261 U.S. 525, 546 (1923), Lochner v. New York, 198 U.S. 45, 53.54, 57 (1905).

119 . And even those cases that interlaced such claims with indications of a balancing test, see note 118 supra, sowed the seeds of their own reversal. See text at notes 120.21 infra. A claim that $\mathrm{X}$ weighs more than $\mathrm{Y}$ will have little persuasive or precedential value if it is bracketed with an indefensible assertion that $Y$ is nothing.

120. Adair v. United States, 208 U.S. 161,172 (1908), quoted morc fully at p. 992 supra. See also, e.g., Lochner v. New York, 198 U.S. 45, 54 (1905).

121. Wrong, that is, if one assigns to the words anything resembling their ordinary meanings. See, e.g., Daniel v. Family Insurance Co., 336 U.S. 220, 224 (1949). One can of course argue that states should also have governments of few and defined powers, that
they should not be vested with broad authority to go after whatever they regard as evils. But the Federal Constitution imposes no such restraint, and according to the test ac. cepted even at the time of Lochner such authority, at least as a matter of federal constitutional law, does exist. 
ously wrong to declare, for example, that restrictions on long working hours cannot reasonably be said to promote health and safety. ${ }^{122}$ Roe's "refutation" of the legislative judgment, on the other, is not obviously wrong, for the substitution of one nonrational judgment for another concerning the relative importance of a mother's opportunity to live the life she has planned and a fetus's opportunity to live at all, can be labeled neither wrong nor right. The problem with Roe is not so much that it bungles the question it sets itself, ${ }^{123}$ but rather that it sets itself a question the Constitution has not made the Court's business. It looks different from Lochner-it has the shape if not the substance of a judgment that is very much the Court's business, one vindicating an interest the Constitution marks as special-and it is for that reason perhaps more dangerous. Of course in a sense it is more candid than Lochner. ${ }^{124}$ But the employment of a higher standard of judicial review, no matter how candid the recognition that it is indeed higher, loses some of its admirability when it is accompanied by neither a coherent account of why such a standard is appropriate nor any indication of why it has not been satisfied.

\section{V}

I do wish "Wolf!" hadn't been cried so often. When I suggest to my students that Roe lacks even colorable support in the constitutional text, history, or any other appropriate source of constitutional doctrine, they tell me they've heard all that before. When I point out they haven't heard it before from me, I can't really blame them for smiling.

But at least crying "Wolf!" doesn't influence the wolves; crying "Lochner!" may. Of course the Warren Court was aggressive in enforcing its ideals of liberty and equality. But by and large, it altempted to defend its decisions in terms of inferences from values the Constitution marks as special. ${ }^{125}$ Its inferences were often controversial, but just as

122. It is possible, of course, that I am here time-bound, and that the vrongness of Lochner et al. is obvious only because a half century of commentary has made it so. While I cannot rebut this, I am inclined to doubt it. In those decisions the Court stated the applicable tests in language much the same as would bc used today-language the dissents cogently demonstrated could not be reconciled with the results. That vievis with which one disagrees can be reasonable nonetheless was a concept hardly new to lawyers even in 1900.

123. But compare 93 S. Ct. at 732 with Doe v. Bolton, 93 S. Ct. 739 (1973). See also pp. 922-26 supra.

124. With respect to the Equal Protection Clause, by way of contrast, the Court has taken to claiming it is simply applying the traditional rationality standard, whether it is or not. For a more optimistic view of the development, see Gunther, Foreurord: In Search of Evolving Doctrine on a Changing Court: A Mlodel for a Nicuer Equal Protection, 86 HARv. L. REv. 1 (1972).

125. See note 97 supra. The "footnote 4 " argument suggested in note 85 supra re. sponds not so much to any clear constitutional concern with equality for women (but 
often our profession's prominent criticism deigned not to address them on their terms and contented itself with assertions that the Court was indulging in sheer acts of will, ramming its personal preferences down the country's throat-that it was, in a word, Lochnering. One possible judicial response to this style of criticism would be to conclude that one might as well be hanged for a sheep as a goat: So long as you're going to be told, no matter what you say, that all you do is Lochner, you might as well Lochner. Another, perhaps more likely in a new appointee, might be to reason that since Lochnering has so long been standard procedure, "just one more" (in a good cause, of course) can hardly matter. Actual reactions, of course, are not likely to be this selfconscious, but the critical style of offhand dismissal may have taken its toll nonetheless.

Of course the Court has been aware that criticism of much that it has done has been widespread in academic as well as popular circles. But when it looks to the past decade's most prominent academic criticism, it will often find little there to distinguish it from the popular. Disagreements with the chain of inference by which the Court got from the Constitution to its result, if mentioned at all, have tended to be announced in the most conclusory terms, and the impression has often been left that the real quarrel of the Academy, like that of the laity, is with the results the Court has been reaching and perhaps with judicial "activism" in general. ${ }^{126}$ Naturally the Court is sensitive to criticism of this sort, but these are issues on which it will, when push comes to shove, trust its own judgment. (And it has no reason not to: Law professors do not agree on what results are "good," and even if they did, there is no reason to assume their judgment is any better on that issue than the Court's.) And academic criticism of the sort that might (because it should) have some effect-criticism suggesting misperceptions in the Court's reading of the value structure set forth in the document from which it derives its authority, or unjustifiable inferences it has drawn from that value structure-has seemed

see U.S. CoNST. amend. XIX) as to the unavoidable obligation to give "principled" content to the facially inscrutable Equal Protection Clause. See pp. 948.49 infra. Virtually everyone agrees that classifications by race were intended to be and should be tested by a higher than usual standard, and that at least some others-though the nature and length of the list are seriously disputed-are sufficiently "racelike" to merit comparable treatment. See, e.g., Graham v. Richardson, 403 U.S. 365 (1971). The problem thus becomes one of identifying those features of racial classifications that validly compel the deviation from the usual standard, and in turn those classifications that share those features.

126. See, e.g., Kurland, Foreword: "Equal in Origin and Equal in Title to the Legislative and Executive Branches of Government, 78 HARv. L. REv. 143, 144.45, 149, 168, 175 (1964). 
for a time somehow out of fashion, the voguish course being simply to dismiss the process by which a disfavored result was reached as Lochnering pure and simple. But if the critics cannot trouble themselves with such details, it is difficult to expect the Court to worry much about them either.

This tendency of commentators to substitute snappy dismissal for careful evaluation of the Court's constitutional inferences-and of course it is simply a tendency, never universally shared and hopefully on the wane-may include among its causes simple laziness, boredom and a natural reluctance to get out of step with the high-steppers. But in part it has also reflected a considered rejection of the view of con. stitutional adjudication from which my remarks have proceeded. There is a powerful body of opinion that would dismiss the call for substantive criticism-and its underlying assumption that some constitutional inferences are responsible while others are not-as naive. For, the theory goes, except as to the most trivial and least controversial questions (such as the length of a Senator's term), the Constitution speaks in the vaguest and most general terms; ${ }^{127}$ the most its clauses can provide are "more or less suitable pegs on which judicial policy choices are hung." 128 Thus anyone who suggests the Constitution can provide significant guidance for today's difficult questions either deludes himself or seeks to delude the Court. Essentially all the Court can do is honor the value preferences it sees fit, and it should be graded according to the judgment and skill with which it does so. ${ }^{120}$

One version of this view appears to be held by President Nixon. It is true that in announcing the appointment of Justices Powell and Rehnquist, he described a "judicial conservative"-his kind of Justice -as one who does not "twist or bend the Constitution in order to perpetuate his personal political and social views." 130 But the example he then gave bore witness that he was not so "naive" after all.

As a judicial conservative, I believe some court decisions have gone too far in the past in rweakening the peace forces as against the criminal forces in our society. ... [T]

127. See, e.g., A. Bicker, supra note 89, at 84-92; A. BickeI, TuE Supresse Coutst AND THE IDEA OF Progress 177 (1970); Mendelson, On the Meaning of the First Amendment: Absolutes in the Balance, 50 CALIF. L. REv, 821 (1962).

128. Linde, supra note 97 , at 254.

129. The Court will continue to play the role of the omniscient and strive toward omnipotence. And the law reviews will continue to play the game of evaluating the Court's work in light of the fictions of the law, legal reasoning, and legal history rather than deal with the realities of politics and statesmanship.

Kurland, supra note 126 , at 175.

130. 7 Weekly Comp. of Presidential Documents 1431 (Oct. 25, 1971). 
not be denied the legal tools they need to protect the innocent from criminal elements. ${ }^{131}$

That this sort of invitation, to get in there and Lochner for the right goals, can contribute to opinions like Roe is obvious. In terms of process, it is just what the President ordered.

The academic version of this general view is considerably more subtle. It agrees that the Court will find little help in the Constitution and therefore has no real choice other than to decide for itself which value preferences to honor, but denies that it should necessarily opt for the preferences favored by the Justices themselves or the President who appointed them. To the extent "progress" is to concern the Justices at all, it should be defined not in terms of what they would like it to be but rather in terms of their best estimate of what over time the American people will make $\mathrm{it}^{132}$-that is, they should seek "durable" decisions. ${ }^{133}$ This, however, is no easy task, and the goals that receive practically all the critics' attention, and presumably are supposed to receive practically all the Court's, are its own institutional survival and effectiveness. ${ }^{134}$

Whatever the other merits or demerits of this sort of criticism, it plainly is not what it is meant to be-an effective argument for judicial self-restraint. For a Governor Warren or a Senator Black will rightly see no reason to defer to law professors on the probable direction of progress; even less do they need the Academy's advice on what is politically feasible; and they know that despite the Court's history of frequent immersion in hot water, ${ }^{135}$ its "institutional position" has been getting stronger for 200 years.

Roe is a case in point. Certainly, many will view it as social progress. (Surely that is the Court's view, and indeed the legislatures had been moving perceptibly, albeit too slowly for many of us, toward relaxing

131. Id. at 1432 .

132. See generally A. Bickel, The Supreme Court and the Idea of Prockess (1970). Professor Bickel's thought is of course much richer than it is here reported. But the catchier aspects of a person's work have a tendency to develop a life of their own and on occasion to function, particularly in the thinking of others and perhaps to an extent even in the author's own, without the background against which they werc originally presented. Cf. note 138 infra.

133. See Hart, Foreword: The Time Chart of the Justices, 73 Harv. L. REv. 81, 99 (1959). See also A. Bicket, supra note 127, at 99; Kurland, Earl Warren, the "IVarrcn Court," and the Warren Myths, 67 Mich. L. REv. 353, 357 (1968). Cf. Karst, Invidious Discrimination: Justice Douglas and the Return of the "Natural-Lau-Duc-Process" Formula, 16 U.C.L.A.L. REv. 716, 746-48 (1969); Karst \& Horowitz, supra note 106, at 79.

134. E.g., A. BrCKEL, supra note 127, at 95; Kurland, Toward a Political Supreme Courl, 32 U. ChI. L. Rev. 19, 20, 22 (1969).

135. See generally W. Murphy, Congress and the Court (1962); C. Warkin, 'TiE Supreme Court in United States History (rev. ed. 1932). 
their anti-abortion legislation.) ${ }^{130}$ And it is difficult to see how it will weaken the Court's position. Fears of official disobedience are obviously groundless when it is a criminal statute that has been invalidated. ${ }^{137}$ To the public the Roe decision must look very much like the New York Legislature's recent liberalization of its abortion law..$^{135}$ Even in the unlikely event someone should catch the public's ear long enough to charge that the wrong institution did the repealing, they have heard that "legalism" before without taking to the streets. Nor are the political branches, and this of course is what really counts, likely to take up the cry very strenuously: The sighs of relief as this particular albatross was cut from the legislative and executive necks seemed to me audible. Perhaps I heard wrong-I live in the Northeast, indeed not so very far from Hyannis Port. It is even possible that a constitutional amendment will emerge, though that too has happened before without serious impairment of the Position of the Institution. But I doubt one will: Roe v. Wade seems like a durable decision.

It is, nevertheless, a very bad decision. Not because it will perceptibly weaken the Court-it won't; and not berause it conflicts with either my idea of progress ${ }^{\mathbf{1 3 9}}$ or what the evidence suggests is society's's0-it doesn't. It is bad because it is bad constitutional law, or rather because it is not constitutional law and gives almost no sense of an obligation to try to be. ${ }^{141}$

136. In the past several years, however, a trend toward liberalization of abortion statutes has resulted in adoption, by about onc-third of the States, of less stringent laws, most of them patterned after the ALI Mlodel Penal Code....

$93 \mathrm{~S}$. Ct. at 720.

By the end of 1970 , four other States had repealed criminal penalties for abortions performed in early pregnancy by a licensed physician, subject to stated procedural and health requirements. Alaska Stat. \$ 11.15 .060 (1970); Hawaii Rev. Stat. \$ 453.16 (Supp. 1971); N.Y. Penal Code \$ 125.05 (McKinncy Supp. 1972-1973); Wash. Rev. Code $\$ \$ 9.02 .060$ to 9.02 .080 (Supp. 1972) . . . .

Id. at 720 n.37.

137. As opposed to the invalidation of a police practice. Cf. Mfiranda v. Arizona, 334

U.S. 436 (1966). See also, e.g., Engel v. Vitalc, 370 U.S. 421 (1962).

138. Even the headline in The New York Times announced: "High Court Rules Abortions Legal [sic] the First 3 Months." N.Y. Times, January 23, 1973, p. 1, cols. 1.8. 139. See pp. 926-27 supra. Of course there are some possible uses of the decision that scare me, particularly when it is considered in conjunction (a) with some of this Court's motions relating to a mother's "waiver" of AFDC assistance, see Wyman v. James, 400 U.S. 309 (1971), and (b) with Buck v. Bell, 274 U.S. 200 (1927), which was indecd relied on by the Court in Roe, $93 \mathrm{~S}$. Ct. at 727 , and cited without apparent disapproval in Justice Douglas's concurrence, id. at 759. But those are quite different cases I'm conjuring up.

140. See note 136 supra. But cf. Abortion, TuE New Rerunuc, Fcb. 10, 1973, at 9: [I]f the Court's guess concerning the probable and desirable direction of progress is wrong, it will nevertheless have been imposed on all 50 states, and imposed permanently, unless the Court itself should in the future change its mind. Normal legis. lation, enacted by legislatures rather than judges, is happily not so rigid, and not

so presumptuous in its claims to universality and permanence.
141 . In judicial review, the line between the "juridical" and the "Iegislative" mode does not run between "strict constructionists" and competing theorists of constitu- 
I am aware the Court cannot simply "lay the Article of the Constitution which is invoked beside the statute which is challenged and ... decide whether the latter squares with the former."142 That is precisely the reason commentators are needed.

[P]recisely becalise it is the Constitution alone which warrants judicial interference in sovereign operations of the State, the basis of judgment as to the Constitutionality of state action must be a rational one, approaching the text which is the only commission for our power not in a literalistic way, as if we had a tax statute before us, but as the basic charter of our society, setting out in spare but meaningful terms the principles of government. ${ }^{\mathbf{1 4 3}}$

No matter how imprecise in application to specific modern fact situations, the constitutional guarantees do provide a direction, a goal, an ideal citizen-government relationship. They rule out many alternative directions, goals, and ideals. ${ }^{144}$

And they fail to support the ruling out of others.

Of course that only begins the inquiry. Identification and definition of the values with which the Constitution is concerned will often fall short of indicating with anything resembling clarity the deference to be given those values when they conflict with others society finds important. (Though even here the process is sometimes more helpful than the commentators would allow.) Nor is it often likely to generate, fullblown, the "neutral" principle that will avoid embarrassment in future cases. ${ }^{145}$ But though the identification of a constitutional connection is only the beginning of analysis, it is a necessary beginning. The point that often gets lost in the commentary, and obviously got

tional interpretation. Rather, it divides constructionists and non-constructionists, those who do and those who do not see judicial review as a task of construing the living meaning of past political decisions-a division in which the alternating lib. ertarianism and conservatism of the late Justices Black and Harlan werc on the same side.

Linde, supra note 97, at 254-55 (footnote omitted).

142. United States v. Butler, 297 U.S. 1, 62 (1936).

143. Poe v. Ullman, 367 U.S. 497, 539-40 (1961) (Harlan, J., dissenting).

144. Wright, Professor Bickel, The Scholarly Tradition, and the Supreme Court, 84

Harv. L. Rev. 769, 785 (1971) (footnote omitted).

145. See generally Ely, supra note 28.

Starting from a clearly unconstitutional course of action-and I have trouble secing the unconstitutionality of a tax exemption for only Caucasian children as a contro. versial assumption-and attempting to explain why it is unconstitutional in terms of a theory capable of acceptable and consistent application to other areas, is a perfectly sensible way of developing constitutional doctrine.

Id. at 1262. I might have made (even more) explicit that the action around which the search for the "principled" approach is to be centered should be one-and, to paraphrase myself, $I$ have trouble seeing the example $I$ chose as controversial in this regard-whose impermissibility is established by values traceable to the Constitution. 
lost in Roe, is that before the Court can get to the "balancing" stage, before it can worry about the next case and the case after that (or even about its institutional position) it is under an obligation to trace its premises to the charter from which it derives its authority. A neutral and durable principle may be a thing of beauty and a joy forever. But if it lacks connection with any value the Constitution marks as special, it is not a constitutional principle and the Court has no business imposing it. ${ }^{146} \mathrm{I}$ hope that will seem obvious to the point of banality. Yet those of us to whom it does seem obvious have seldom troubled to say so. ${ }^{147}$ And because we have not, we must share in the blame for this decision.

146. But see, e.g., Hart, supra note 133, at 99, quoted in part in Bickel, Foreuord: The Passive Virtues, 75 HaRv. L. REv. 40, 41 (1961):

[T] he Court is predestined ... to be a voice of reason, changed with the creative function of discerning afresh and of articulating and developing impersonal and durable principles....

But discerning constitutional principles afresh is one thing; developing them, no matter how neutral and durable, is quite another. An institution charged with looking after a set of values the rest of us have entrusted to it is significantly different from one with authority to amend the set.

147. But see, e.g., Linde, supra note 97. Cf. Bork, Neulral Principles and Some First Amendment Problems, 47 IND. .L.J. 1, 6-11 (1971), espousing the general view of con. stitutional adjudication espoused here, but characterizing Grisuold as a typical Warren Court product, id. at 7 , in order to buttress the more general claim-equally unfair in my view-that one cannot accept that general view and at the same time generally approve the work of that Court. Id. at 6. See Griswold v. Connecticut, 381 U.S. 479, 527 n.23 (1965) (Black, J., dissenting). 